\title{
The Silent Run: New Issues and Outcomes for University-Industry Relations in Brazil
}

\author{
Paulo Antônio Zawislak', Gustavo Dalmarco²
}

\begin{abstract}
In order to develop innovations, companies are establishing University-Industry (U-I) relations which are explained in theories like the Triple Helix. Maybe this traditional view it is not enough to describe what happens in Brazil. Followed by a growth of articles published internationally, companies in technologically stable industries seem to be incorporating high-tech outcomes from universities, boosting sectors that once were apparently inert. This research will propose a different approach on U-I relations, focusing on the Knowledge Flow. Results show that agriculture companies are increasing their relations as much as engineering companies. Such relations are mainly based on raw technologies or applied solutions. Start-up firms' relations are mainly based on informal contacts and patents are not used to protect technologies. The Silent Run shows that companies which appear to be technologically stable are now upgrading trough U-I, and patents does not seem to be the first option when protecting new technologies.
\end{abstract}

Keywords: Brazil; university-industry relations; innovation; knowledge flow; start-up firms.

\footnotetext{
' Universidade Federal do Rio Grande do Sul - UFRGS- Programa de Pós-Graduação em Administração. Rua Washington Luiz, 855. Centro - Porto Alegre- RS - Brazil CEP: 90.010-000 - Phone: +55 5 I 33083728 / Fax: +55 5 I 3308 399I- Email:paz@ea.ufrgs.br

${ }^{2}$ Universidade Federal do Rio Grande do Sul - UFRGS- Programa de Pós-Graduação em Administração. Rua Washington Luiz, 855.

Centro - Porto Alegre- RS - Brazil CEP: 90.010-000 - Phone: +55 5133083728 / Fax: +55 513308 399I- Email: gdalmarco@ea.ufrgs.br
} 


\section{Introduction}

Innovation is one of the drivers of economic growth. By developing innovative activities, companies jump ahead of competitors, improving efficiency, organizational structure or creating new market opportunities. Cooperating with powerful partners from science and research is very helpful in this context. Innovation is not a merely adaptation of current knowledge, available on the market. Technological change is majorly born in the knowledge frontier, originated from scientific and technological research in its state of the art (Dosi, 1988).

Traditionally, companies find two ways of developing technological innovations: (I) developing autonomous research activities; (2) through alliances with scientific labs from universities or public research institutes. Historically, in developed countries, the first one has been practiced by big companies (Nelson \& Rosenberg, 1993), as a way of protecting state-of-the-art knowledge. But, due to cost reduction policy, companies are focusing on applied research, leaving basic research for scientific labs (Auerswald, Branscomb, Demos and Min, 2005). On the other hand, in emergent countries, most companies don't have internal capabilities to develop innovative activities (De Negri, Salerno and Castro, 2005). As a consequence, relationships with other companies and research centres seem to be a way of complement their limited assets.

Looking forward to complement their assets, companies are getting closer to universities. In the University-Industry Relations $(U-I)^{3}$, the state-of-the-art knowledge generated by universities and research centers is a source of new technological applications for firms. Different from current patterns of technological solution available in the market, U-I may be a source of new knowledge, which may be responsible for the development of disruptive technologies.

University-Industry relations are explained in many theories, like the Sabato's triangle (Sabato \& Botana, 1975) and the many modes of the Triple-Helix (Etzkowitz, 2003). Sabato's triangle explains how each vertice (government, industry and science) interact with each other or with society, in a one-way flow of information. Now the TripleHelix shows a dynamic interaction between the same three vertices, while government establishes the policies and industry and science are constantly interacting.

Both theories describes the actors involved in U-I relations, and the channels of knowledge transfer. According to the country's environment, universities or companies establish different ways of knowledge transfer, according to the channels used. For example, Austrian companies find contract research and consulting as the most important channel of knowledge transfer, followed by collaborative research and joint PhD supervision (Schartinger, Rammer, Fischer and Fröhlich, 2002). On the other hand, in UK the most common way of knowledge transfer is trough meetings and conferences, followed by consultancy and contract research (D'este \& Patel, 2007).

But maybe this traditional view is not enough to explain what is happening in emerging countries like Brazil. Despite the mature technological base, where only $7 \%$ of Brazil's industry is considered high technological intensity (FEE, 2009), Brazilian companies seem to be changing its regular pattern. Technologically stable industry are surprisingly incorporating some high-tech outcomes from now universities, boosting sectors that once were inert. Adding to this, the increase in quantity and quality of Brazilian articles evidences the boom of researches being conducted Indicators show a 165\% increase in articles published (from 19,436 in 2007 to 32,100 in 2009), being classified as the 13th country in articles published in 2009, representing a world share of $2.69 \%$ (MCT, 2010). As an output, new partnerships with companies and spinoff firms are taking scientific research to the market, improving economic development.

Considering this scenario, there is a need to find different ways to explain how $U$-I can drive technological innovation. Instead of describing actors and channels trough which knowledge is transferred, it is necessary to determine the knowledge content that is being transferred, and which institution is responsible for establishing the interaction.

\footnotetext{
${ }^{3}$ Here we are not considering the traditional linear view of university-industry relations, but a dynamic knowledge transfer between both institutions.
} 
This article proposes a different approach on UniversityIndustry relations, focusing on content and direction of the knowledge flow between the institutions. Considering the different levels of knowledge contained in universities (scientific) and companies (technologic), innovation cannot be "measured" based only on the way knowledge is transferred. The research will encompass the analysis of primary and secondary data, describing what seems to be a new pattern of university-industry relations.

This work is composed by five more sections. Initially, it will be described the actual standards for U-I relations, reviewing classical and brand new articles about the subject, followed by section three where will be presented the knowledge flow proposed, which adds a dynamic pattern to the actual static view of U-I. The following section presents the method that will be used to conduct this research, and the fifth section describes the results. The last section highlights the conclusion of the study, and discusses the silent run of university-industry relations in Brazil.

\section{Describing Science-Industry Relations}

Most relations between scientific institutions and companies involve some kind of knowledge, with different levels of scientific and applied knowledge according to the relation. It also involves the establishment of partnerships, complementing the particular assets of each institution.

Knowledge is the relevant and useful information, based at least partially on a real experience (Leonard \& Sensiper, 1998). In order to improve knowledge, science experiments and applied experiences are united, creating new technologies (Nelson, 1959; Marglin, 1990). In general, technology emerges from man's necessity to overcome barriers, as the lack of strength, precision or even more knowledge (Zawislak, 1995). In a broader sense, technology is any kind of knowledge which was improved by science.

Looking forward the improvement of technological capabilities, companies are establishing relations with different partners, sharing cost and risks (Dodgson, 1993). In U-I relations companies also aim to complement their own resources (Penrose, 1995; Langlois, 2009), creating new assets and incrementing their absorptive capacity (Cohen \& Levinthal, 1990; Nelson, 2000).
This is the main purpose of university-industry relations: to complement companies' resources by producing high qualified scientific knowledge. But this kind of relationship is not restrained to universities and industries. The U-I process concerns the approach of institutions responsible for creating scientific knowledge (universities, public and private research institutions, etc) with institutions responsible for the knowledge economic application (industries, start-up firms, etc.) (Nelson, 1959; Dosi, 1988).

There are some concept in which $U-I$ relations were based on. Sabato's triangle describes three fundamental actors to support research activities based on technological innovation, boosting economic development: Government, Industry and Scientific-Technological Infrastructure (Sabato \& Botana, 1975).

In an updated view of Sabato's triangle, the Triple Helix from Etzkowitz (2003) also tries to integrate science, technology and economic development among the same three actors: government, industry and university. But Etzkowitz's model is based on a helix, where knowledge flows mainly between industry to scientific actors, with government remaining in a position of policy development and monitoring.

Besides universities and companies, government is also an important part of the tripod of $U-I$ relations, mainly due to laws, policies and funds. Many companies base their activities in R\&D and Innovation only when supported by governmental funds. Looking forward U-I relations, governmentproposes laws and incentives for such relations, in addition to research funds for university-industry joint projects and venture capital for start-up companies.

Considering empirical researches on $\mathrm{U}-\mathrm{I}$ relations, many studies describe their characteristics, the entrepreneurship process, how knowledge is transferred between companies and university and even the influence of U-I on articles' productivity (De Clercq \& Arenius, 2006; Audretsch \& Keilbach, 2007; Azagra-Caro, 2007; Bozeman \& Gaughan, 2007; Burger-Helmchen, 2008; Manjarrés-Henríquez, Gutiérrez-Gracia and Vega-Jurado, 2008; Yusuf, 2008; Boardman \& Ponomariov, 2009; Czarnitzki, Glänzel and Hussinger, 2009). 
Adding to this, regional studies (in Brazil, Taiwan, Kazakhstan, Portugal, among others) analyzes the innovative activity of firms inside science parks, and the channels used to transfer knowledge among institutions (Cohen, Nelson and Walsh, 2002; Etzkowitz, Mello and Almeida, 2005; Perkmann \& Walsh, 2007; D'este \& Patel, 2007; Bekkers \& Freitas, 2008; Lin \& Tzeng, 2009; Østergaard, 2009; Radosevic \& Myrzakhmet, 2009; Yang, Motohashi and Chen, 2009; Ratinho \& Henriques, 2010).

But, as it can be seen, actual research on universityindustry relations are focusing mainly on empirical studies of established concepts, like the Triple Helix. The tripod Government - Industry - University was mainly used as a guideline to many of the studies, from science parks to entrepreneurship.

This paper will address through university-industry relations new indicators of knowledge transfer from university to industry, and vice-versa. The new proposal will try to capture new issues if $U-I$ relations in Brazil, especially in low tech industrial sectors. Both companies and universities have unique knowledge that, when used together, can generate technological innovations. But maybe traditional indicators of U-I relations are not enough to capture such knowledge flow.

A new dynamic approach will be proposed, based on the direction and content of the knowledge flow between institutions. Differently from previous views, the knowledge flow is mainly characterized by the institution responsible for establishing the interaction, and the content of knowledge transferred. According to these two characteristics, it may be possible to determine how the dynamic flow occur during the interaction, and how is this flow stimulating innovative activities.

\section{University-Industry Relations based on the Knowledge Flow}

University-Industry relations aim to approach industries' applied knowledge with scientific knowledge created by universities/research centres, leading to new advanced practices (i.e. innovative). In order to enhance knowledge in both institutions, it is necessary to establish a knowledge flow between them, based on a dynamic transfer of scientific and applied knowledge. The knowledge flow (figure $0 \mathrm{I}$ ) is defined by the difference on the levels of knowledge between institutions (Wang \& Lu, 2007).

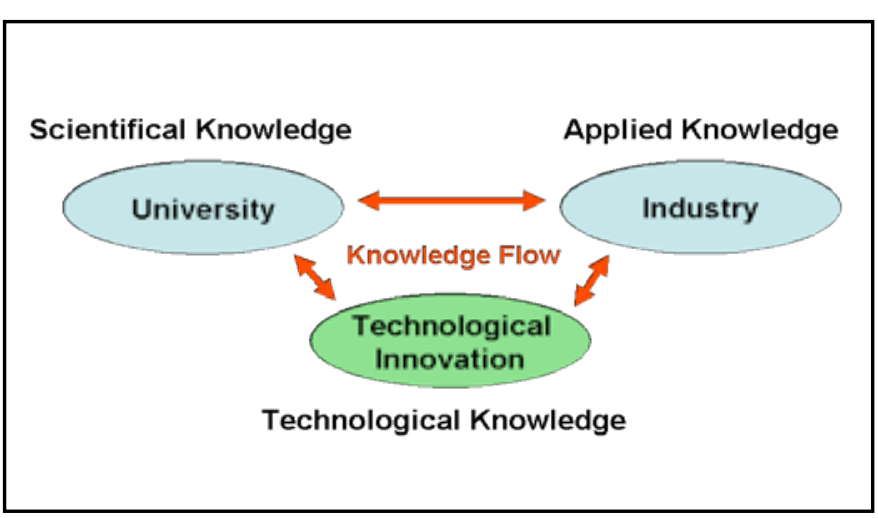

Figure I -Knowledge Flow between the University and Industry

While knowledge absorbed by companies may qualify them, making it possible to produce innovative products, knowledge absorbed by university may guide scientific research results closer to society's needs. As a consequence, the union of both kinds of knowledge may boost socio-economic development, through innovative activities.

The knowledge flow proposed is based on four factors: actors, channels, direction and content. Many articles which analyze the components of $\mathrm{U}-\mathrm{I}$ have describe the actors responsible for settling the relation, as academic scientists, entrepreneurs, company's director or researcher, or university technology transfer office (Siegel, Waldman, Atwater and Link, 2003; Azagra-Caro, 2007; Boardman \& Ponomariov, 2009).

Considering the channels used for knowledge transfer, empirical researches were conducted in order to identify the main channels used in university-industry relations (Table 0I). These articles describe the purpose of such channels, as information for new projects, information for project completion, relations between channels and knowledge areas and which are the main channels used by different industrial sectors (Schartinger et al,, 2002; Bekkers \& Freitas, 2008; Østergaard, 2009; Zawislak \& Dalmarco, 2010). 


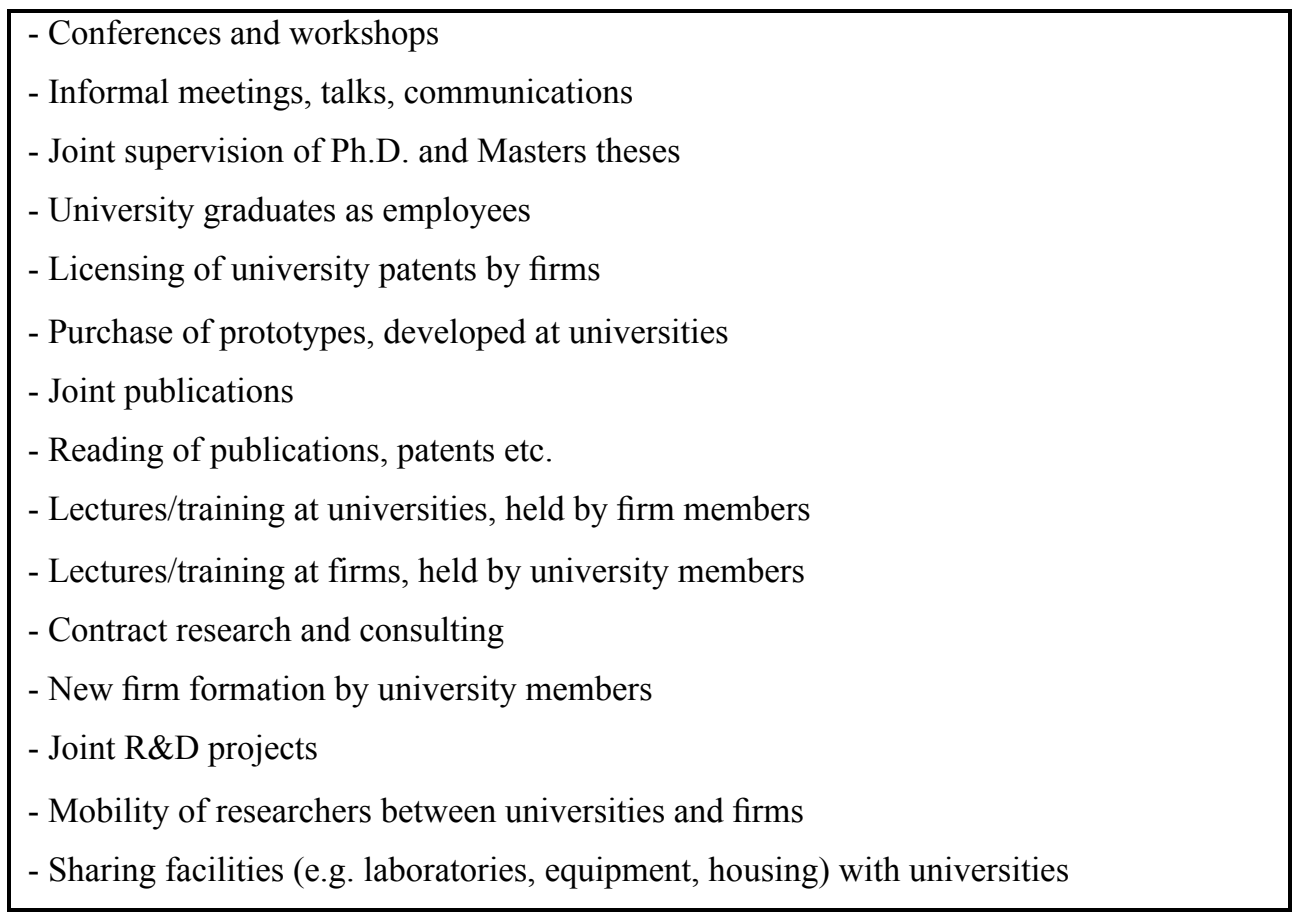

Table 0 I - Main channels used for knowledge transfer.

In view of the dynamic of U-I relations, knowledge should flow continuously between institutions, developing technological capabilities. The new approach proposed is basedon the direction of theknowledgeflow, and thecontent of knowledge transferred. And, in order to categorize the content of knowledge exchanged between the institutions, three indicators for knowledge flow were considered:

i) Knowledge Flow from University to Industry ${ }^{4}$, where the scientific institution leads the relation, offering scientific research results to companies (Reamer, Icerman and Youtie, 2003; Langford, Hall, Josty, Matos and Jacobson, 2006). This flow indicator is mainly represented by two content indicators:

(a) Raw Scientific Results, based on channels like conferences and workshops; reading of publications and patents; and the purchase of prototypes developed at universities (Siegel et al., 2003; Rossel \& Agrawal, 2009). (b) Scientific Knowledge Spillover, based on channels like hiring university graduates and lecture/training of company's researchers (Siegel et al., 2003; Nelson, 2006).

ii) Knowledge jointly shared between university and industry, where the creation and development of scientific and technological knowledge is shared between both institutions (Etzkowitz \& Leydesdorff, 2000; Chesbrough, 2006). This flow indicator is represented by the content indicator of "Scientific-Technological Spillover", which is based on channels as joint publications; joint R\&D projects (Perkmann \& Walsh, 2007); joint supervision of Ph.D. and Masters thesis (Boardman \& Ponomariov, 2009); and also new firm formation by university members (Ranga, Debackere and Von Tunzelmann, 2003; Gilsing, Van Burg and Romme, 20I0).

\footnotetext{
${ }^{4}$ The concept presented here is different from technology push and market pull concepts (Dosi, 1982). Here we only consider indicators based on the channels of knowledge transfer described, and no the offer or demand of technology.
} 
iii) Knowledge flows from industry to university, where industry generates a request, based on marketing demands or internal P\&D problems (Rapini, 2007; Yusuf, 2008). This indicator of flow is based on the following indicators of content:

(a) Applied Knowledge Solutions, where the main channels used are contract research and consulting (Balconi \& Laboranti, 2006); lectures/training at universities (Brennenraedts, Bekkers and Verspagen, 2006); and facilities' sharing (Phillimore, 1999).

(b) Current Technological Solutions, based on the channel of contract research and consulting (Cohen et al., 2002; Rapini, 2007). Differently from the previous content indicator, here the demand is only based on coasts reduction, and doesn't involve any scientific development, only the adaptation of current scientific knowledge to firms needs.

Considering the four factors proposed (summarized in table 02), a research was conducted in Brazil, aiming to identify the silent run of Brazilian university-industry relations. This research was based in questionnaire sent to start-up companies in the south of Brazil, and on a national database of industry relations with academic research groups. 
J. Technol. Manag. Innov. 20II,Volume 6, Issue 2

\begin{tabular}{|c|c|c|c|}
\hline Factor & Description & $\begin{array}{l}\text { Indicators } \\
\end{array}$ & Authors \\
\hline Actors & $\begin{array}{l}\text { Personal } \\
\text { responsible to } \\
\text { establish the } \\
\text { U-I Relations. }\end{array}$ & $\begin{array}{l}\text {-Academic Scientists } \\
\text {-Entrepreneur } \\
\text {-Company Director } \\
\text {-Technology Transfer Office } \\
\text {-Company Researcher }\end{array}$ & $\begin{array}{l}\text { Siegel et al., 2003; Azagra-Caro, 2007; } \\
\text { Boardman and Ponomariov, } 2009\end{array}$ \\
\hline Channels & $\begin{array}{l}\text { Channels } \\
\text { trough which } \\
\text { knowledge is } \\
\text { transferred. }\end{array}$ & $\begin{array}{l}\text {-Conferences and workshops } \\
\text {-Informal meetings, talks, } \\
\text { communications } \\
\text {-Joint supervision of Ph.D. and Masters } \\
\text { theses } \\
\text {-University graduates as employees } \\
\text {-Licensing of university patents by firms } \\
\text {-Purchase of prototypes, developed at } \\
\text { universities } \\
\text {-Joint publications } \\
\text {-Reading of publications, patents etc. } \\
\text {-Lectures/training at universities, held by } \\
\text { firm members } \\
\text {-Lectures/training at firms, held by } \\
\text { university members } \\
\text {-Contract research and consulting } \\
\text {-New firm formation by university } \\
\text { members } \\
\text {-Joint R\&D projects } \\
\text {-Sharing facilities (e.g. laboratories, } \\
\text { equipment, housing) with universities }\end{array}$ & $\begin{array}{l}\text { Schartinger et al., 2002; Bekkers and } \\
\text { Freitas, 2008; Østergaard, 2009; Zawislak } \\
\text { and Dalmarco, } 2010\end{array}$ \\
\hline Direction & $\begin{array}{l}\text { From which } \\
\text { institution } \\
\text { knowledge } \\
\text { flows }\end{array}$ & $\begin{array}{l}\text {-From University to Industry } \\
\text {-Jointly shared between University and } \\
\text { Industry } \\
\text {-From Industry to University }\end{array}$ & $\begin{array}{l}\text { Etzkowitz and Leydesdorff, 2000; Reamer } \\
\text { et al., 2003; Langford et al., 2006; } \\
\text { Chesbrough, 2006; Rapini, 2007; Yusuf, } \\
2008\end{array}$ \\
\hline Content & $\begin{array}{l}\text { Content of } \\
\text { knowledge } \\
\text { transferred } \\
\text { between } \\
\text { institutions }\end{array}$ & $\begin{array}{l}\text {-Raw scientific results } \\
\text {-Scientific Knowledge Spillover } \\
\text {-Scientific-Technological Spillover } \\
\text {-Applied Knowledge Solutions } \\
\text {-Current Technological Solutions }\end{array}$ & $\begin{array}{l}\text { Phillimore, 1999; Siegel et al., 2003; Ranga } \\
\text { et al., 2003; Balconi and Laboranti, 2006; } \\
\text { Nelson, 2006; Brennenraedts et al., 2006; } \\
\text { Perkmann and Walsh, 2007; Rapini, 2007; } \\
\text { Rossel and Agrawal, 2009; Boardman and } \\
\text { Ponomariov, 2009; Gilsing, Van Burg and } \\
\text { Romme, } 2010\end{array}$ \\
\hline
\end{tabular}

Table 02 - Factors that determine the Knowledge Flow 


\section{Research Method}

To better understand $U-I$ relations in emergent countries, this paper proposes a research method divided in two phases. The first will be performed by an analysis of $\mathrm{U}-\mathrm{I}$ relations in Brazil, trough an online database of relations between companies and academic research groups. The second part will be conducted locally in the south of Brazil, trough a survey among start-up firms located in technological incubators.

In order to draw a broader picture of university-industry relations in Brazil, even evaluating how this relations have evolved during the years, It was performed an analysis on the research groups database of CNPq (Brazilian National Council for Scientific and Technological Development). Most Brazilian research groups are registered at CNPq, where they describe their activities, number of students, etc. Among this information they also identify the different relations they have with companies, and through what kind of channels knowledge it is transferred. The database contained, in 2008, 2,726 research groups, that performed some kind of interaction with 4,521 companies (CNPq, 2009). The relations were here described according to the channel of knowledge transfer, divide in 14 different categories.

The second part of the research was conducted among incubated firms from Rio Grande do Sul, Brazil. The survey was used to evaluate how start-up companies established in a technological incubator relate to research groups, describing the direction and content of knowledge transferred. All the incubators contacted were related to a university, and the firms selected have developed some kind of technological product. An on-line survey was created at Google Docs, with 7 open questions and 4 closed questions. The website was sent to managers of 57 firms located in 8 high-tech business incubators, with a response rate of $18 \%$.

\section{Results}

University-Industry relations are mainly described as being one of the drivers of innovation. Approaching scientific research to technological application, the chances of developing innovative products increases considerable. As innovation is at some point responsible for economic development, it seems that $\mathrm{U}-\mathrm{I}$ relations have a role in the current situation in Brazil.

From 2002 to 2008 the number of research groups registered at CNPq grew $213 \%$, while the number of companies relating to them grew on a similar ratio $(\mathrm{CNPq}$, 2009). There are approximately 1.66 companies relating to each research group, in a total of 2,726 research groups. In 2008 the most frequent kind of relation was contract research $(29 \%)$, technology transfer in means of patents and prototypes (16\%), raw scientific results (14\%) and consultancy (12\%). When comparing data over the years, the percentages were almost the same. This shows that even with a visible increase on the number of companies and research groups, the ways of interaction were almost the same along the years.

When describing the area of science of the research groups sample, engineering correspond to $40 \%$ of the total, followed by agriculture science (19\%) and health sciences $(9 \%)$. As it can be seen in table 3 , the same sequence is also true when related to the amount of companies which have relations with these research groups.

\begin{tabular}{|l|c|c|}
\hline \multicolumn{1}{|c|}{ Area of Science } & Number of Companies & Number of Research Groups \\
\hline Engineering & 2,059 & 880 \\
\hline Agriculture Science & 948 & 521 \\
\hline Health Sciences & 462 & 332 \\
\hline
\end{tabular}

Table 03 - Research groups related to companies, by areas of science 
From another perspective, table 04 shows that most companies which have relation to research groups are from agriculture and livestock activity ( $9 \%$ of the sample), followed by education (8\%) and scientific research and development (6\%). The reason why there aren't manufacturing companies in this table is mainly due to the diversity of subdivisions this branch has (machinery, electronic, optics, aerospace, etc.), dividing the amount of companies with relations to universities according to their particular field. On the other hand, agriculture, livestock and services branch includes temporary and permanent farming, horticulture, livestock, and services related to this area, increasing the diversity inside the same denomination.

\begin{tabular}{|c|c|c|}
\hline Branch of Activity & Number of Companies & Number of Research Groups \\
\hline $\begin{array}{c}\text { Agriculture, Livestock and } \\
\text { services related }\end{array}$ & 479 & 459 \\
\hline Education & 441 & 337 \\
\hline $\begin{array}{c}\text { Scientific Research and } \\
\text { Development }\end{array}$ & 337 & 431 \\
\hline
\end{tabular}

Table 04 - Companies related to research groups, by branch of activity

A particular aspect could be extracted from this database. At first look it was interesting that agriculture related areas had so much effort in using the university as a source of new technologies. In order to analyze the real share of companies established in Brazil in relation to those with relations to research groups, the database of U-I relations was compared to the last census of companies in Brazil, available at the Brazilian Institute of Geography and Statistics website (IBGE, 2006).

\begin{tabular}{|c|c|c|c|}
\hline Branch of Activity & $\begin{array}{c}\text { Companies relating } \\
\text { to research groups }\end{array}$ & $\begin{array}{c}\text { Total of companies in } \\
\text { Brazil }\end{array}$ & $\begin{array}{c}\text { Proportion of } \\
\text { companies relating to } \\
\text { research group }\end{array}$ \\
\hline $\begin{array}{c}\text { Agriculture, Livestock and } \\
\text { services related }\end{array}$ & 574 & 42,874 & $1.34 \%$ \\
\hline Manufacturing Industry & 1,192 & 530,635 & $0.22 \%$ \\
\hline
\end{tabular}

Table 05 - Comparison between the amount of companies relating to research group and the total amount of companies

As described in table 05, comparing to the total amount of companies, agriculture related business interact more to research groups than engineering related business. This may support the growing advantage in agro commodities that Brazil is obtaining ahead of other countries. Table five shows that once technologically stable sector now are investing in scientific knowledge. Especially in agriculture, Brazil is allocating resources for technology development, resulting on an increase in productivity and quality of seeds. After this broader look at the Brazilian scenario, a lo- cal research was conducted with start-up firms in the south of Brazil. The local research aimed to analyze the knowledge flow from firms located in academic high tech incubators to academic labs. As the broader research demonstrated that not only university-industry relations are growing in Brazil, but that companies also search for contract research and technology transfer when in such relations, a local research may shed new light on how are incubated companies establishing relations with universities, in the aspects of the knowledge flow. 
Analyzing the respondents answers regarding the direction of knowledge, most firms (seven out of ten) said that the director of the company was the one who established the U-I relations. But, in our case, four of those seven respondents where both company's director and academic researcher. For this reason it was not clear which "part" of the respondent was looking forward to the partnership, the entrepreneur or the researcher part. This could be answered by the reason to establish the relation, whether it was to develop a new product, or to use technical support. Surprisingly, the most frequent reason to start the relationship (seven out of ten) was to have access to non refundable government funds for R\&D. Besides that, four out of ten companies also seek for U-I relations when solving technical problems, developing new products and access to scientific results holding the second most frequent reason.

About the channels used for knowledge transfer, it was asked the importance of each channel, according to respondent's opinion, (table 06), and then which channels did the ten respondent used during his relations with university (table 07).

\begin{tabular}{|l|c|c|}
\hline \multicolumn{1}{|c|}{ Channel } & Mean & SD \\
\hline Lectures/training at firms, held by university members & 4.78 & 0.44 \\
\hline Sharing facilities (e.g. laboratories, equipment, housing) with universities & 4.67 & 0.50 \\
\hline University graduates as employees & 4.67 & 0.71 \\
\hline
\end{tabular}

Table 06 - The importance of each knowledge transfer channel

\begin{tabular}{|l|c|}
\hline \multicolumn{1}{|c|}{ Channel } & Frequency \\
\hline Informal meetings, talks, communications & 7 \\
\cline { 1 - 1 } Conferences and workshops with firm and university participation & 6 \\
\hline Reading of publications, patents etc. & \\
\cline { 1 - 1 } University graduates as employees & 5 \\
\hline Research Contract / Consulting & \\
\hline Sharing facilities with universities & \\
\hline Joint Research & \\
\hline
\end{tabular}

Table 07 - Knowledge transfer channels most used during $U-I$

Table six shows that what incubated companies find most important is to receive training, use facilities and hire graduates. Joint research, for example, is fourth in order of importance, with the same mean as lectures/training at universities, held by firm members.

Informal meetings has a particular characteristic among start-ups, as it had an average mean when considering its importance (4.00), but it is the most used channel among the companies researched. The same happened to conferences and workshops, that got the same mean of 4.00. Despite the small sample, there are evidences that while on the one hand companies seek for technical assistance through informal contacts inside universities, they seek for scientific results outside the university, in conferences and workshops. This demonstrates that when looking for new technologies, companies prefer those which are in a higher development level, instead of looking for joint development in emergent research. 
In matters of patents, interviewed companies demonstrated a lack of interest in legally protecting their products. Only three of them had requested patent protection, while one of this three had just one product in portfolio. Considering all the companies, there are 65 products in total, with less then $5 \%$ of them protected by intellectual property rights. This shows that a traditional indicator of innovation has to be carefully used when aiming to measure innovation in start-up firms of emergent economies, where intellectual property are still to expensive to apply, and takes too long to be granted.

Summing up, the analysis of secondary data showed a large number of $U-I$ relations in areas which are considered low technology (according to OCDE classification). Adding to this, our survey with incubated companies shows a large number of informal relations and participations in conferences. In a recent research, Østergaard (2009) shows that, in 100 informal relations between company and university researchers, only $3 \mathrm{I}$ were of medium (24) or high (7) value of knowledge. This data support our and other authors (Cohen et al., 2002; Rapini, 2007) view that usually companies seek for technical knowledge at universities, instead of state-of-the-art knowledge.

\section{New issues on Brazil's University-Industry Relations}

University-Industry relations aim to approach companies to scientific research, resulting on the development of innovative products. In emergent countries like Brazil, where industries in general do not have enough capabilities to develop high tech R\&D, start-up firms located in academic incubators are considered a solution to upgrade the industrial sector. Remembering Pavitt's sectoral patterns (1984), firms based on science are intensive in innovative activities, while those which are supplier dominated have their technological trajectory defined in terms of cutting coasts.

But what if supplier dominate sectors change their cutting costs trajectory, and start investing in technology for diversifying and qualifying products. This is the silent run that seems to be happening in Brazil. In front of a, with some exceptions, technologically stable industry, sectors based on commodities are evolving, moving from a costs reduction trajectory to intensive in science products, developing partnerships with universities and research centres.

This new standard can be seen on the research groups' secondary data analysis. The manufacturing and agriculture industry are the two biggest sectors in relations with scientific research groups (both represent $51 \%$ of the sample), and follow the same pattern of relations. They seem to be using at least some of the high technology created by research groups, as the most frequent kind of relation from both industrial sectors is contract research, followed by patent and transfer of prototypes. Areas such as agronomy, animal breeding and food science and technology have most of the relations with companies in the field of agriculture. When looking into the engineering research groups, the research area which has most relations is electric engineering, followed by metallurgy and materials.

But what calls our attention is that the agriculture sector has more relations to research groups than Engineering industry. While $1.34 \%$ of Brazilian agriculture companies have some kind of relation with academic research groups, in the engineering industry this relation falls to $0.22 \%$.

This brings a new scenario of emergent countries, where low tech industrial sectors as agriculture ${ }^{15}$ is developing new technologies based on scientific research, overcoming international competitors. As can be seen, from 2000 to 2008 Brazil became the third biggest exporter of agricultural products, ahead of China, Australia and Canada (WTO, 2009).

This new behavior is mostly based on governmental investment, who is investing in research and development through EMBRAPA, a governmental research institute. EMBRAPA received I3\% of governmental R\&D investments in 2009 , working with 2125 researches (23\% with MSc and $76 \%$ with $\mathrm{PhD}$ ) (Embrapa, 2009). Based on equipments, seeds and soil treatment research, Brazil is achieving historical production levels. Nowadays agriculture is one of the responsible for boosting Brazilian economy, and knowledge is being transferred to seeds producers through partnerships between EMBRAPA and private companies (Fuck \& Bonacelli, 2009).

\footnotetext{
${ }^{5}$ According to the OECD Classification of Manufacturing Industries Based on Technology
} 
Considering the new outcomes brought up by the database of research groups, it was performed a survey among incubated firms. This survey was conducted in university business incubators, and the main respondents were engineering and IT firms. As academic business incubators aims to stimulate academic researchers to start their own enterprise, we expected them to be more favorable to receive and use scientific knowledge in their activities, what in the end was not totally true. The survey was based on the channels used for knowledge transfer between university and company, who was actively responsible for establishing the relation with the university and the main reasons for this relation.

Survey data shows that the most important channels are still based on the regular linear U-I process, where companies only receive knowledge (mainly articles, training and alumni hiring) from university. In order to develop company's assets, relations with university should be based on joint activities, evolving the knowledge base of both institutions.

When considering the most used channels, transferring knowledge through informal meetings is the most frequent in our results. Although recent articles demonstrate that such channel of knowledge transfer rarely contribute to high value knowledge transfer between university and industry (Østergaard, 2009), other articles present that this kind of knowledge transfer is considered one of the most important link between scientists and companies (Cohen et al., 2002; D'Este \& Patel, 2007).

About the motivation to enter $U-I$ relations, most companies stand that they are looking for government funds access, followed by solving technical problems and developing new products. We already expected that having access to funds should be important, but we also expected that technology based firms would search more for scientific knowledge, instead of technical solutions.

Another important aspect from the surveyed firms is that they don't seem to find patents worthy, as most of the products commercialized by them don't have intellectual property rights. This is actually a common behavior in this sector in Brazil, as the patent takes time to be granted and money to register and keep monitoring it. In the end, considering the constant technology evolution, by the time a competitor have copied the technology the company has already developed a new version of it.
Results demonstrate on the one hand the growing willingness of Brazilian companies to use $U-I$ relations to improve their products and processes. But on the other, incubated companies who were supposed to use the knowledge from research groups in their products, are much more interested in receiving governmental funds to support their own research projects.

When we used our indicators of knowledge flow, we though the actor responsible for establishing the relations between incubated companies and universities would be more clear. As it could be seen, the same person (academic researcher and entrepreneur) is responsible to decide how his company will develop new R\&D projects. $\mathrm{He}$ can either have relations with its own research lab (i.e. students and equipments), and by this submit projects for governmental funds, or conduct research only inside his company. The knowledge flow in this situation is much more related to the entrepreneurial activity of the researcher, who is performing final improvements on his spin-off product. In this case, scientific research is only used to solve technical problems, sometimes also based on informal contacts. But this doesn't mean that at some point of development scientific results weren't more evident.

Crossing information of channels used for knowledge transfer, actors involved in the process, and the motivation to join U-I relations, it is possible to deduce the content of knowledge used by start-up companies. As described before, the technological finishing of start-up products require much more current technological solutions to solve development problems then raw scientific results or joint research. The entrepreneur is in most cases also a scientific researcher, who has incorporated research assets to its company activities. This "double activity" also blurs the responsible for establishing the relation as university and company are represented by the same person, the entrepreneur researcher.

But unfortunately this same deduction can't be made from the information acquired from relations between research groups and companies. The fact that agriculture companies are establishing contract research partnerships with universities doesn't explain the content of knowledge of such relations, neither how this companies absorb the knowledge transferred. Anyway, this sector is taking advantage of scientific research to improve their production process, obtaining advantages in quantity and quality of production ahead of international competitors. 
But it is not just agriculture that is evolving. Other big Brazilian companies from supposed technologic stable sector are becoming global players with investments on scientific results. Gerdau's Metallurgic and even Petrobras are developing their activities based on U-I relations, improving productivity and quality of their products.

Although a bigger involvement of industry into joint research should be considered the perfect scenario, the participation of research groups in contract research shows that companies are getting closer to scientific research, developing sectors more favorable to the Brazilian economic environment. Such environment seem to be more open to particular aspects of U-I relations, as the lack of patent register of start-up companies, or the approach of technologic stable sector to high-tech research. This particular situation shows that the use of new indicators of university-industry relations may be feasible to emergent countries. The knowledge flow of $U$-I relations may capture particular aspects of such relations, explaining how technological stable companies use scientific knowledge in their routines.

The main limitation for this study was the short number of respondent firms. As many start-ups have academic researchers as a part of their staff, it was expected a bigger participation on the survey. Other limitation was on the secondary data about agriculture innovative activities. IBGE has a specific survey for innovation in manufacturing industries, but not for agriculture companies. As a future research we aim to conduct a survey with start-up and established companies from agriculture area, trying then to compare the achieved results.

This research was a preliminary analysis of the Brazilian industrial sector, and how their relations with university were happening. It was able to shed light on new aspects of university industry relations that were not clear when considering the traditional view of universityindustry relations. The silent run of Brazilian companies demonstrate that on the one hand stable industrial sectors are using scientific research as a source of applied solutions, and on the other that high tech companies are basing their relations with universities more on informal meetings and conferences then articles and joint research.

\section{References}

AUDRETSCH, D.B., Keilbach, M. (2007) The Theory of Knowledge Spillover Entrepreneurship. Journal of Management Studies, 44(7), 1242-1254

AUERSWALD, P., Branscomb, L., Demos, N., Min, B.K. (2005). Understanding private-sector decision making for early-stage technology development: a "between invention and innovation project." Report No. NIST GCR 02 84IA. National Institute of Standards and Technology, US Department of Commerce. http://www.atp.nist.gov/eao/ gcr02-84la/gcr02-84la.pdf [Accessed January, 10 2009].

AZAGRA-CARO, J.M. (2007) What type of faculty member interacts with what type of firm? Some reasons for the delocalisation of university-industry interaction. Technovation 27(II), 704-7I5.

BALCONI, M., Laboranti, A. (2006) University-Industry Interactions in Applied Research: The Case of Microelectronics. Research Policy 35 (10), 1616-1630.

BEKKERS, R., Freitas, I.M.B. (2008) Analysing knowledge transfer channels between universities and industry: To what degree do sectors also matter? Research Policy 37(10), 1837-1853.

BOARDMAN, P.C., Ponomariov, B.L. (2009) University researchers working with private companies. Technovation 29 (2), 142-153

BOZEMAN, B., Gaughan, M. (2007) Impacts of grants and contracts on academic researchers' interactions with industry. Research Policy 36(5), 694-707

BRENNENRAEDTS, R., Bekkers, R., Verspagen, B. (2006) The different channels of university-industry knowledge transfer: Empirical evidence from Biomedical Engineering. Eindhoven Centre for Innovation Studies. Working Paper 06.04 .

BURGER-HELMCHEN, T. (2008) Plural-entrepreneurial activity for a single start-up: A case study. Journal of High Technology Management Research. 19(2), 94-102. 
CHESBROUGH, H.W. (2006) Open innovation: a new paradigm for understanding industrial innovation. In Chesbrough, H., Vanhaverbeke, W., West, J. (eds), Open Innovation: Researching a New Paradigm. Oxford: Oxford University Press.

CNPQ (2009) Diretórios dos Grupos de Pesquisa do Brasil. http://dgp.cnpq.br/censos/index.htm [Accessed December, 10 2009]

COHEN, W., Levinthal, D. (1990) Absorptive capacity: a new perspective on learning and innovation. Administrative Science Quarterly. 35(I), 128-152.

COHEN, W.M., Nelson, R.R., Walsh, J.P. (2002) Links and Impacts: The Influence of Public Research on Industrial R\&D. Management Science. 48(I), I-23.

CZARNITZKI, D., Glänzel, W., Hussinger, K. (2009) Heterogeneity of patenting activity and its implications for scientific research Research Policy 38(I), 26-34

D'ESTE, P., Patel, P. (2007). University-industry linkages in the UK: What are the factors underlying the variety of interactions with industry? Research Policy 36(9), 1295-1313.

DE CLERCQ, D., Arenius, P. (2006) The Role of Knowledge in Business Start-up Activity. International Small Business Journal. 24(4), 339-358.

DE NEGRI, J. A., Salerno, M. S., Castro, A. B. (2005) Inovações, Padrões Tecnológicos e Desempenho das Firmas Industriais Brasileiras. In: De Negri, J. A., Salermo, M. S. (orgs). Inovações, padrões tecnológicos e desempenho das firmas industriais brasileiras. Brasília: IPEA

DODGSON, M. (1993) Technological collaboration in Industry: Strategy, policy and internationalization in innovation. Ed. Routledge.

DOSI, G (1988) The nature of the innovative process. in: Dosi, G, C Freeman, R Nelson, L Soete (eds.). Technical Change and Economic Theory. London, Pinter.

EMBRAPA - Empresa Brasileira De Pesquisa Agropecuária. (2009) General information. http://www.embrapa.br/ [Accessed August, 22 2009]
ETZKOWITZ, H. (2003) Innovation in Innovation: The triple Helix of University-Industry-Government Relations. Social Science Information, 42(3), 293-337.

ETZKOWITZ, H., Mello J.M.C., Almeida, M. (2005) Towards "meta-innovation" in Brazil: The evolution of the incubator and the emergence of a triple helix. Research Policy 34(4), 4II-424.

ETZKOWITZ, H., Leydesdorff, L. (2000) The dynamics of innovation: from National Systems and "Mode 2" to a Triple Helix of university-industry-government relations. Research Policy 29(2), 109-123.

FEE - Foundation of Economics and Statistics (2009) Intensidade tecnológica da indústria gaúcha: como estamos? Carta de Conjuntura FEE I8(9), I.

FUCK, M.P., Bonacelli, M.B.M. (2009) Institutions and Technological Learning: Public-Private Linkages in Agricultural Research in Brazil and Argentina. Journal of Technology Management and Innovation, 4(2), 33-43.

GILSING, V.A., Van Burg, E., Romme, A.G.L. (2010) Policy principles for the creation and success of corporate and academic spin-offs. Technovation 30(I), 12-23.

IBGE-Instituto Brasileiro de Geografia e Estatística.(2006) Demografia das Empresas 2006. http://www.ibge.gov.br/ home/estatistica/economia/demografiaempresa/2006/demoempresa2006.pdf. [Accessed December, 10 2009].

LANGFORD, C.H., Hall, J., Josty, P., Matos, S., Jacobson, A. (2006) Indicators and outcomes of Canadian university research: Proxies becoming goals? Research Policy 35(I0), I586-1598

LANGLOIS, R.N. (2009) Economic Institutions and the Boundaries of the Firm: The Case of Business Groups. Department of Economics Working Paper Series Working Paper 2009-23. http://www.econ.uconn.edul working/2009-23.pdf. [Accessed June, 12 2010]

LEONARD, D., Sensiper, S. (1998) The role of Tacit Knowledge in Group Innovation. In: California Management Review. 40(3), I12-132 
LIN, C-H., Tzeng, G-H. (2009) A value-created system of science (technology) park by using DEMATEL. Expert Systems with Applications, 36(6), 9683-9697.

MANJARRÉS-HENRÍQUEZ, L., Gutiérrez-Gracia, A., Vega-Jurado, J. (2008) Coexistence of university-industry relations and academic research: Barrier to or incentive for scientific productivity. Scientometrics, 76(3), 56I-576.

MARGLIN, S.A. (1990) Loosing touch: the cultural conditions of worker accommodation and resistance. in: Marglin, F.A., Marglin, D. Dominating Knowledge: Development, Culture, and Resistance. Ed. Oxford.

MCT - Ministry of Science and Technology. (2010) Número de artigos brasileiros, da América Latina e do mundo publicados em periódicos científicos indexados pela Thomson/ISI, 198I-2009. http://www.mct.gov.br/index. php/content/view/57/0.html. [Accessed March, 19 20l0].

NELSON, R.R. (2000) The Sources of Economic Growth. Harvard University Press.

NELSON, R.R., Rosenberg, N. (1993) Technological Innovation and National Systems. In: Nelson, RR. (Ed). National Innovation Systems: a Comparative Study. Oxford Univ. Press, New York.

NELSON, R.R. (1959) The Simple Economics of Basic Scientific Research. The Journal of Political Economy. 67(3), 297-306.

NELSON, R.R. (2006) As Fontes do Crescimento Econômico. Ed. Unicamp, Campinas, SP.

ØSTERGAARD, C.R. (2009) Knowledge flows through social networks in a cluster: Comparing university and industry links. Structural Change and Economic Dynamics. 20(3), 196-210.

PAVITT, K. (1984) Sectoral patterns of technical change: towards a taxonomy and a theory. Research Policy, I3 (6), 343-373.

PENROSE, E. (1995) The Theory of the Growth of the Firm. New York: Oxford University Press.
PERKMANN, M., Walsh, K. (2007) University-Industry Relationships and Open Innovation: Towards a Research Agenda. International Journal of Management Reviews. 9(4), 259-280.

PHILLIMORE, J. (1999) Beyond the linear view of innovation in science park evaluation An analysis of Western Australian Technology Park. Technovation 19(II), 673-680.

RADOSEVIC, S., Myrzakhmet, M. (2009) Between vision and reality: Promoting innovation through technoparks in an emerging economy Technovation 29(10), 645-656.

RANGA, L.M., Debackere, K., Von Tunzelmann, N. (2003) Entrepreneurial universities and the dynamics of academic knowledge production: A case study of basic vs. applied research in Belgium. Scientometrics 58(2), 30I-320.

RAPINI, M.S. (2007) Interação Universidade-Empresa no Brasil: Evidências do Diretório dos Grupos de Pesquisa do CNPq. Estudos Econômicos, 37(I), 2II-233.

RATINHO, T., Henriques, E. (2009) The role of science parks and business incubators in converging countries: Evidence from Portugal Technovation, v.30, n.4, p.278-290.

REAMER, A., Icerman, L., Youtie, J. (2003) Technology Transfer and Commercialization: Their Role in Economic Development. Economic Development Administration, U.S. Department of Commerce, Washington.

ROSSEL, C., Agrawal, A. (2009). Have university knowledge flows narrowed? Evidence from patent data. Research Policy. 38(I), I-I3.

SÁBATO, J.A., Botana, N. (1975) La ciencia y la tecnología en el desarrollo futuro de América latina. In: Sabato, JA. El pensamiento latinoamericano em la problemática: ciencia, tecnología, desarrollo e dependencia. Buenos Aires: Paidós.

SCHARTINGER, D., Rammer, C., Fischer, M. M., Fröhlich, J. (2002) Knowledge interactions between universities and industry in Austria: sectoral patterns and determinants. Research Policy 3I(3), 303-328. 
SIEGEL, D.S., Waldman, D.A., Atwater, L.E., Link, A.N. (2003) Commercial knowledge transfers from universities to firms: improving the effectiveness of universityindustry collaboration. Journal of High Technology Management Research. 14(I), III-133.

WANG, Y., Lu, L. (2007) Knowledge transfer through effective university-industry interactions: Empirical experiences from China. Journal of Technology Management in China. 2(2), I19-133.

WTO - World Trade Organization (2009) International Trade Statistics 2009. http://www.wto.org/english/res_el statis_e/its2009_e/section2_e/iil6.xls [Accessed December, 18 2009].

YANG, C-H., Motohashi, K., Chen, J-R. (2009) Are new technology-based firms located on science parks really more innovative?: Evidence from Taiwan. Research Policy, 38(I), 77-85.

YUSUF, S. (2008). Intermediating knowledge exchange between universities and businesses. Research Policy 37, II67-II74.

ZAWISLAK, P.A.; Dalmarco, G. (2010) The Silent Run: New Issues and Outcomes for University-Industry Relations in Brazil. In: 19th International Conference on Management of Technology, 2010, Cairo, Egypt.

ZAWISLAK, P.A. (1995) Relação entre Conhecimento e Desenvolvimento: essência do progresso técnico. Análise, Porto Alegre , 6(I): 125-149. 
J. Technol. Manag. Innov. 20II,Volume 6, Issue 2 